\title{
STRENGTH OF CORNER TENON JOINTS MADE FROM THERMO-TREATED WOOD
}

\author{
Seid Hajdarevic, Murco Obucina, Ibrahim Busuladzic \& Alen Ibrisevic
}
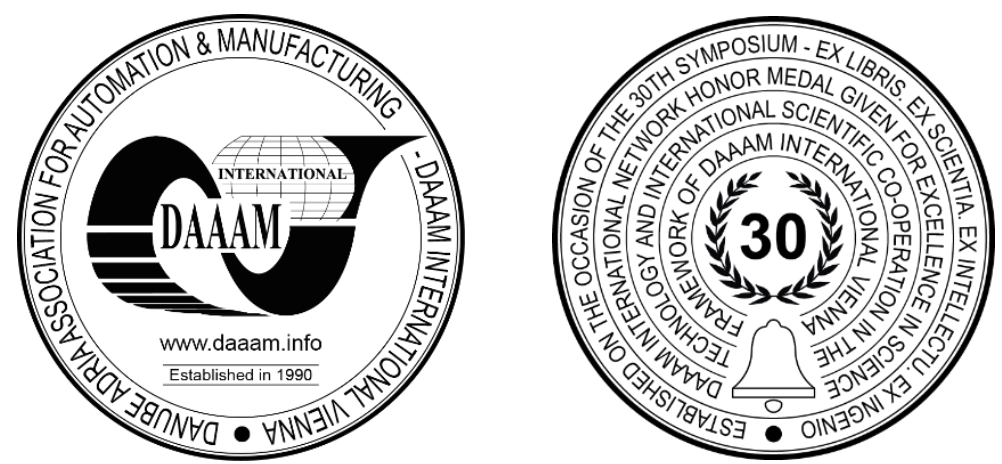

This Publication has to be referred as: Hajdarevic, S[eid]; Obucina, M[urco]; Busuladzic, I[brahim] \& Ibrisevic, A[len] (2020). Strength of Corner Tenon Joints Made from Thermo-Treated Wood, Proceedings of the 31st DAAAM International Symposium, pp.0137-0143, B. Katalinic (Ed.), Published by DAAAM International, ISBN 978-3-90273429-7, ISSN 1726-9679, Vienna, Austria

DOI: $10.2507 / 31$ st.daaam.proceedings.018

\begin{abstract}
This paper investigated the strength of corner tenon joints made from natural ash wood and thermally-modified ash wood. Previously, an analysis of selected physical and mechanical properties of natural and thermal-treated ash wood was performed. The results showed that thermo-treated ash wood in relation to natural ash wood has a remarkable lower wood moisture content, $23 \%$ lower bending strength and 25\% higher compressive strength parallel to grain. The joints strength (maximal moment), calculated on the basis of measured maximal applied loads (maximal force), were compared for a set of natural ash wood joints and a set of thermo-treated ash wood joints. Results of the tests showed that, for the same test specimen configurations, the maximum force of joints made of natural ash wood was higher than the force values of joints made of thermo-treated ash wood, i.e. the strength of thermo-treated joints has $50 \%$ lower value compared to the strength of the natural ash joints. It has been shown that thermal modification changes the technical properties of wood and that therefore thermally modified wood has a remarkable reduced construction quality.
\end{abstract}

Keywords: ash wood; thermo-treated wood; tenon joint; joint strength; bending strength

\section{Introduction}

Thermo-treated wood is commonly used in the construction of outdoor furniture and other wood structures that require increased durability and resistance to water or weather. Numerous wood thermo-treatment processes to increase biological durability, weather resistant and dimensional stability which are used in industrial practice differ from each other in various process conditions, but all processes treat natural wood at elevated temperature (in the range of $160 \mathrm{C}$ to $260 \mathrm{C}$ ) in the environment without oxygen. Thermo-treatment process enhances a certain physical property of wood, but it also has a notable impact on other technical properties of wood. Also, mechanical properties of thermo-treated wood are one of numerous factors that can affect the strength of tenon joints, as well as the load-carrying capacity of structures made of thermo-treated wood. Thermal-treated wood is produced to get better performances of wood, particularly in improvements of specific and important properties of wood, i.e. dimensional stability, decay and weathering resistance [1]. The process changes chemical properties of wood resulting in decrease in equilibrium moisture content and wettability $[2],[3]$. 
Important negative aspects of thermal treatment of wood are loss in mass and, consequently, degradation of main mechanical properties of wood, i.e. bending strength which limits the potential use of thermo-treated wood in structural applications [4]. Strength of tenon joint is affected by tenon size. Tenon length had a dominant effect on the bending moment capacity [5], [6], [7], [8], [9], while the bending moment capacity is related to shoulder width and tenon width [10], [11]. Polyvinyl acetate glue was found to be the most appropriate adhesive which is used to obtain this type of joints [12]. The thermo process caused a reduction of dowel holds, screw holds, dowel-joint and mortise and tenon joint performance [13]. The highest value of nail withdrawal strength is found with the unmodified wood and it is gradually decreased with increasing the treatment temperature [14]. The dowel joints made of thermo-treated wood have lower compressive and tensile failure forces than the joints made of untreated wood [15], [16]. Heat treatment, wood type, and joint type have a considerable effect on the bending strength of T-type mortise and tenon joints [17], [18].

This paper investigated the strength of corner mortise and tenon joints made of thermo-treated wood and untreated wood (control samples). Previously, the basic mechanical properties (compression strength parallel to grain and bending strength) of treated and untreated wood were determined. The objectives were to determine the difference between the basic mechanical properties of thermo-treated and untreated wood and to determine the effect of thermo-treated wood on the joint bending moment that is the joint strength indicator. The aim of the study was to explore the capabilities and limitations of use of common tenon joints made of thermo-treated wood.

\section{Experimental method}

The wood material, natural wood and thermo-treated wood, that was used to make specimens was procured from the same supplier. All tested specimens were made from ash wood (Fraxinus sp.). In the thermo-treatment process, the wood was heated up to $200{ }^{\circ} \mathrm{C}$ under the steam atmosphere and without chemical additives. The thermo-treatment of wood was performed in a chamber and the process took 5 hours. The compressive strength parallel to the grain and the bending strength of the natural ash wood and thermo-treated ash were evaluated in accordance with the procedures described in ISO 13061-17 (2017) and ISO 13061-3 (2014), respectively, before testing the corner joints [19], [20]. The tests were carried out on a universal testing machine, Fig. 1. The compressive strength parallel to the grain was tested on 10 standard samples while the bending strength was tested on 9 standard samples for each group of materials (natural wood and thermo-treated wood).

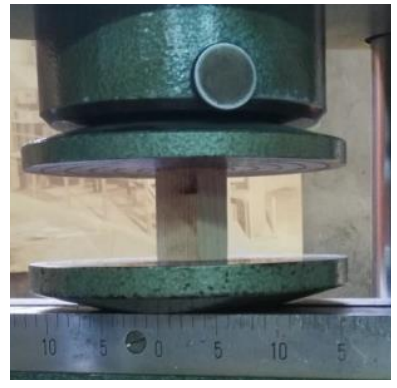

a)

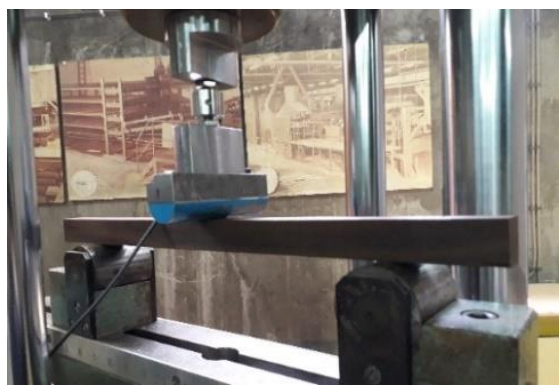

b)

Fig. 1. Testing of mechanical properties of ash and thermo-treated ash: a) compressive strength parallel to the grain, b) bending strength

The joints samples were composed of a mortise piece (stile) and tenon piece (rail). The first set of joints contained 10 joints made of natural ash wood, while the second set of joints contained 10 joints made of thermo-treated ash wood. The shape and dimensions of the test specimens of joints is shown in Fig. 2.
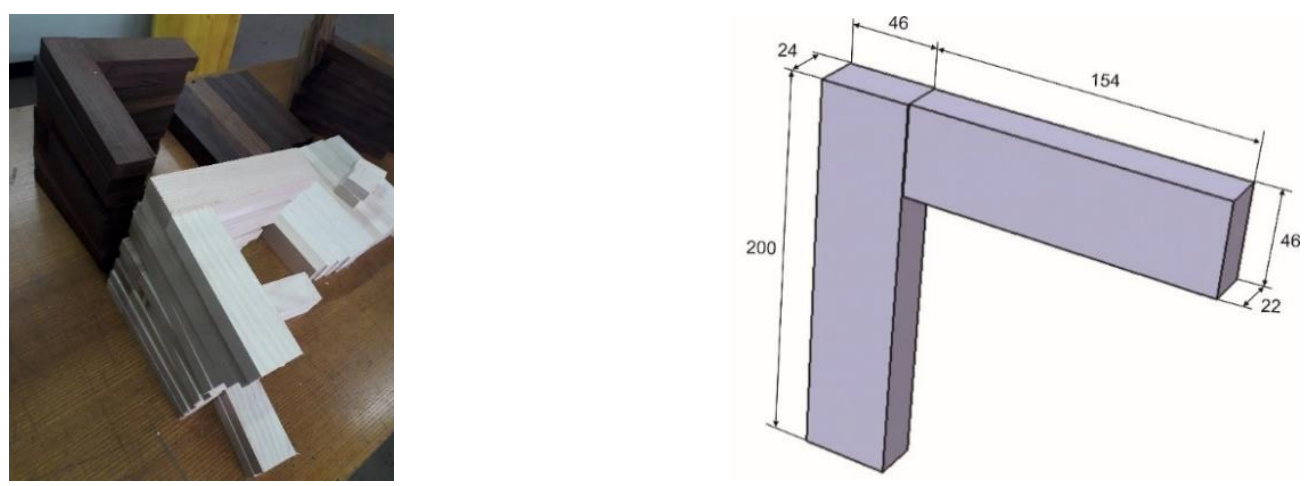

Fig. 2. Corner mortise and tenon joints: a) specimens (natural ash and thermo-treated ash), b) shape and dimensions of the specimens 
The corner tenon joints were with round peg shape and tenon length of $30 \mathrm{~mm}$. The joints made of natural ash wood were with mortise and tenon interference fit, while the joints made of the thermo-treated ash had no interference fit due to brittleness of such wood material, Fig. 3.

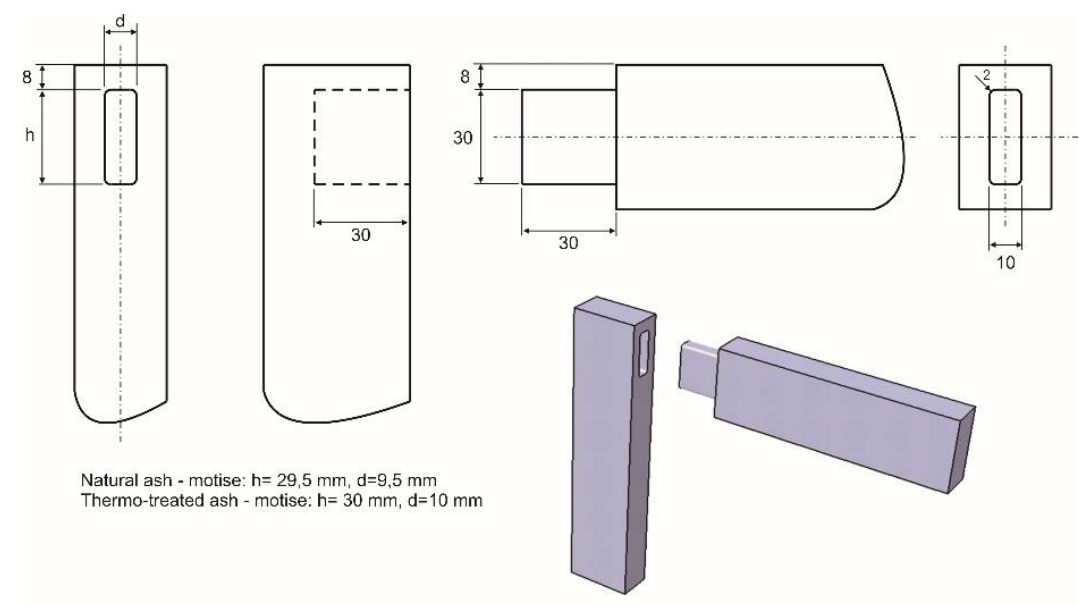

Fig. 3. Tenon and mortise (natural ash and thermo-treated ash) size of joints

The loading diagram of corner joints and test setup is shown in Fig. 4. Roller supports were set up on the lower joint edges while the load was applied to the joint in a manner that corresponded to the tension of specimen. The test was carried out on a universal testing machine with load cell and inductive displacement transducer. Force and displacement along the force line were measured simultaneously until a joint failure.

Maximal moments of the joints were calculated as $M_{\max }=F_{A \max } \cdot a_{A}=F_{B \max } \cdot a_{B}$. The forces $F_{A \max }$ and $F_{B \max }$ are support reactions calculated on the basis of the ultimate applied load Fmax and static conditions. Distances $\mathrm{a}_{\mathrm{A}}$ or $\mathrm{a}_{\mathrm{B}}$ are moment arms, i.e. perpendicular distance from the support reaction line to the force line. Support reactions were of the same value and obtained based on the trigonometric analysis of isosceles triangle with a known interior angle.

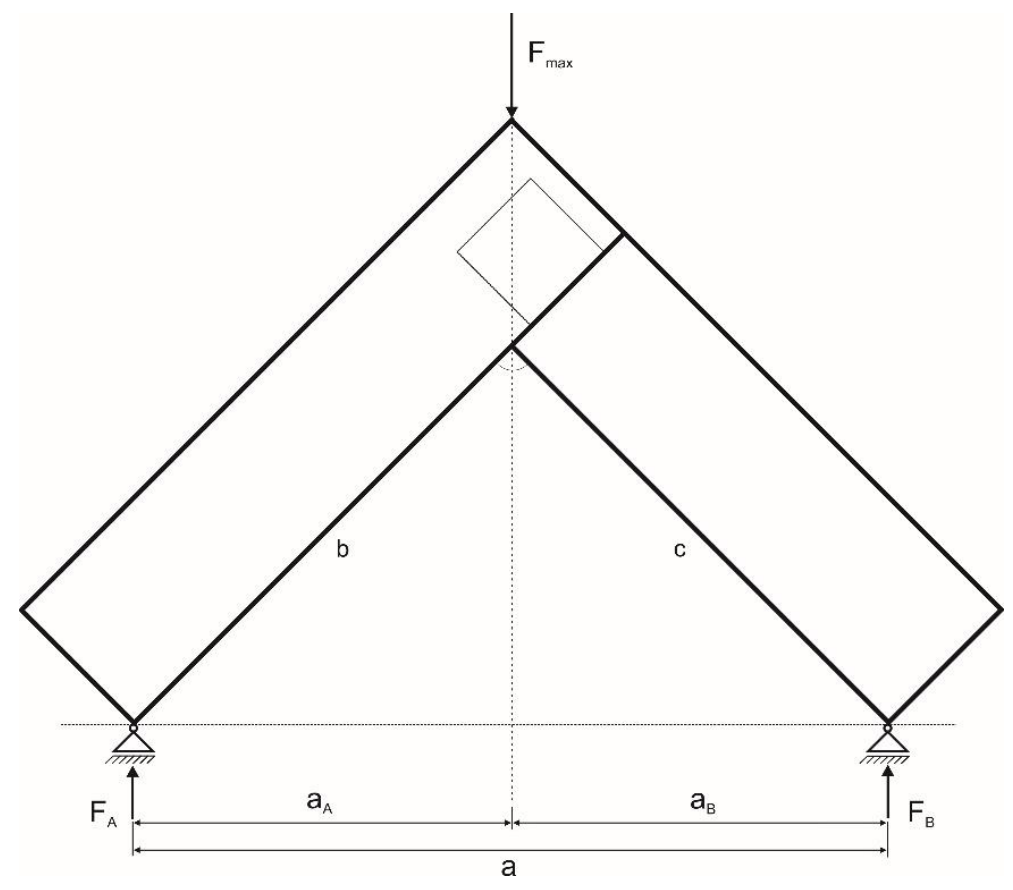

a)
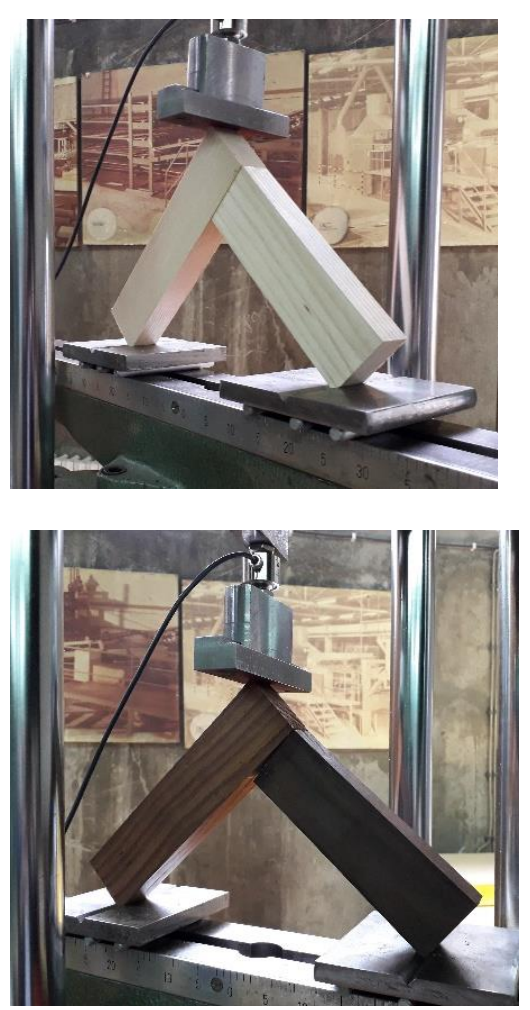

b)

Fig. 4. Joints testing: a) diagram of joint loading, b) set-up of joints in the testing machine

Moisture contents of natural ash wood and thermo-treated ash wood were evaluated in accordance with the procedures described in ISO 13061-1 (2014) after testing [21]. 


\section{Results}

Average values of moisture content of the specimens were $11,01 \%$ and 2,48\% for natural ash wood and thermo-treated ash wood, respectively. The equilibrium moisture content in thermo-treated ash wood is very low compared to untreated ash wood and that is one of the main performances of thermally-modified wood which increases durability of the wood.

Experimental results of compressive strength parallel to grain and bending strength of natural ash wood and thermotreated ash wood are given in Table 1.

\begin{tabular}{|c|c|c|c|c|c|c|c|c|}
\hline \multirow[b]{2}{*}{$\begin{array}{c}\text { Mechanical } \\
\text { properties }\end{array}$} & \multicolumn{4}{|c|}{ Ash wood } & \multicolumn{4}{|c|}{ Thermo-treated ash wood } \\
\hline & $\begin{array}{c}\text { Mean, } \\
\text { MPa }\end{array}$ & $\begin{array}{c}\text { Median, } \\
\text { MPa }\end{array}$ & $\begin{array}{c}\text { Standard } \\
\text { Deviation, } \\
\text { MPa }\end{array}$ & $\begin{array}{c}\text { Coefficient } \\
\text { of } \\
\text { Variation, } \\
\%\end{array}$ & $\begin{array}{l}\text { Mean, } \\
\text { MPa }\end{array}$ & $\begin{array}{c}\text { Median, } \\
\text { MPa }\end{array}$ & $\begin{array}{c}\text { Standard } \\
\text { Deviation, } \\
\text { MPa }\end{array}$ & $\begin{array}{c}\text { Coefficient } \\
\text { of } \\
\text { Variation, } \\
\%\end{array}$ \\
\hline $\begin{array}{c}\text { Compressive } \\
\text { strength } \\
\text { parallel to } \\
\text { grain } \\
\end{array}$ & 49,23 & 49,91 & 7,42 & 15,07 & 61,69 & 67,31 & 8,97 & 14,54 \\
\hline $\begin{array}{l}\text { Bending } \\
\text { strength }\end{array}$ & 104,59 & 106,04 & 49,84 & 21,27 & 80,31 & 83,19 & 27,18 & 33,85 \\
\hline
\end{tabular}

Table 1. Compressive strength parallel to grain and bending strength of ash wood and thermo-treated ash wood

Mean values indicated that compressive strength parallel to grain of thermo-treated wood are $25,3 \%$ higher than the same strength of natural ash wood. The experimental results agree with the literature data which claim that the thermotreated wood has higher strength than natural, untreated wood.

Also, the results show expected differences among the average bending strength of untreated and treated ash wood. The bending strength of thermo-treated wood was $23,2 \%$ lower than the average value for natural ash wood. The bending strength decrease of treated ash wood is within the limits that can be found in literature. Figure 5 shows the curves of force-deflection diagrams of the bending tested specimens.

The diagrams show noticeable differences among the values of ultimate applied force (breaking force) of natural ash wood and thermo-treated ash wood. It can be noticed that the curve of thermo-treated ash wood has a wide defined elastic region that ends with a sudden fracture, while curves of untreated ash have a path that is typical for natural wood. The difference between modulus of elasticity of treated and untreated ash wood was not analysed.

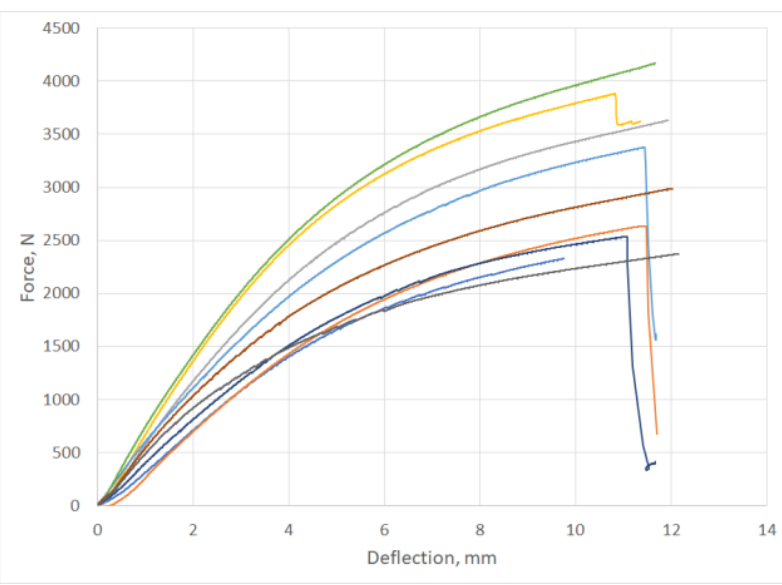

a)

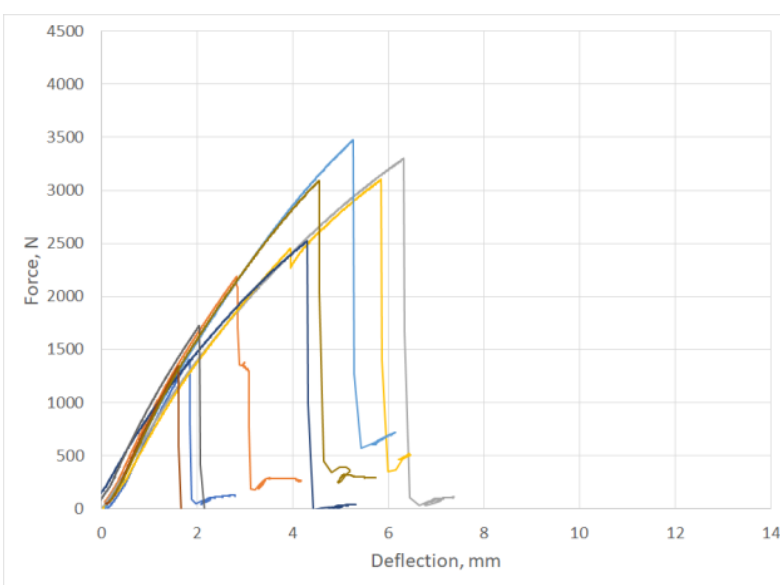

b)

Fig. 5. Working diagram of bending strength testing: a) ash wood, b) thermo-treated ash wood

A difference among the patterns of fractures of treated and untreated ash wood were observed, Fig.6. The thermotreated wood specimens were breaking into smaller sections during the compression strength test, while the specimens used for bending test had clean and brittle fractures. 

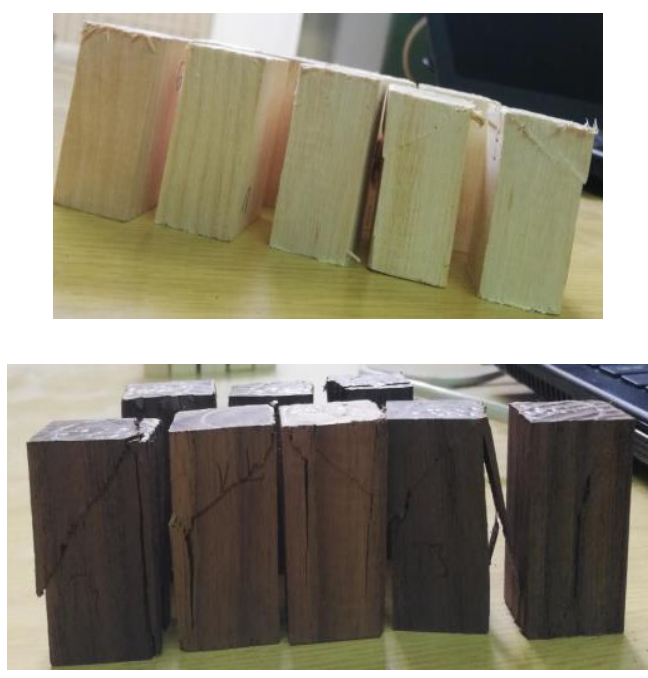

a)

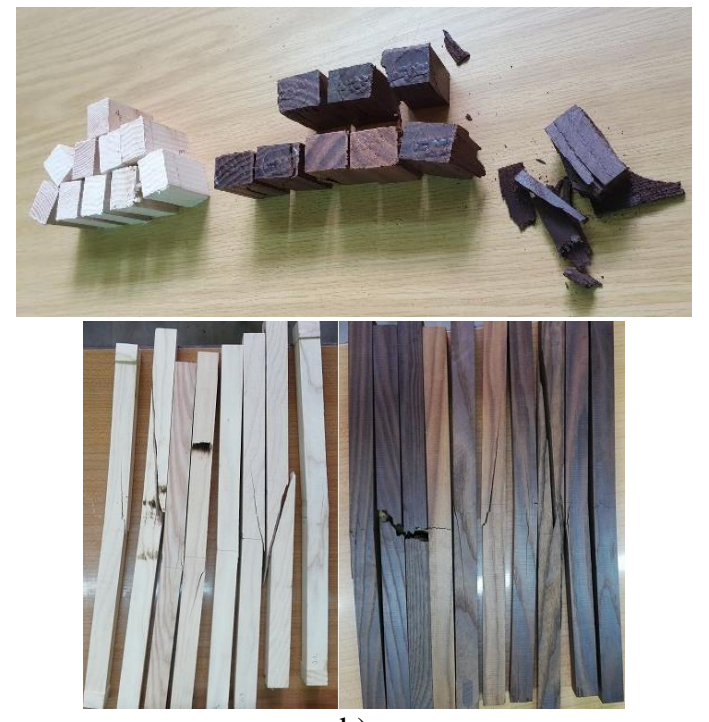

b)

Fig. 6. Untreated and treated wood specimen failures: a) compressive strength parallel to grain testing, b) bending strength testing

Results of maximal force and maximal moment of the corner tenon joints made of untreated and thermo-treated ash wood are given in Table 2. The mean values of maximal force of untreated and treated joints were comparable due to dimensional and shape identity of these two specimen groups of joints, and the maximal force, in this case, is a good indicator of the joint strength. The maximal force mean value of tenon joints made of natural ash wood was remarkably higher than the mean value of tenon joints made of thermo-treated ash wood. The treated ash wood joints had $51.9 \%$ lower mean maximal force than the natural ash wood joints.

\begin{tabular}{|c|c|c|c|c|}
\hline \multicolumn{5}{|l|}{ Strength of joints } \\
\hline \multirow{2}{*}{ No. specimens } & \multicolumn{2}{|c|}{ Tenon joint - ash wood } & \multicolumn{2}{|c|}{ Tenon joint - thermo-treated ash wood } \\
\hline & Max force, $\mathbf{N}$ & Max moment, Nm & Max force, $\mathbf{N}$ & Max moment, Nm \\
\hline 1 & 3816,72 & 207,82 & 3206,75 & 174,61 \\
\hline 2 & 3990,46 & 217,28 & 2916,16 & 158,78 \\
\hline 3 & 4153,97 & 226,18 & 2259,14 & 123,01 \\
\hline 4 & 4190,24 & 228,16 & 1471,50 & 80,12 \\
\hline 5 & 4412,27 & 240,25 & 1957,84 & 106,60 \\
\hline 6 & 3924,99 & 213,72 & 1982,48 & 107,95 \\
\hline 7 & 4326,61 & 235,58 & 1047,82 & 57,05 \\
\hline 8 & 4340,48 & 236,34 & 1434,06 & 78,08 \\
\hline 9 & 4816,74 & 262,27 & 1540,60 & 83,89 \\
\hline 10 & 4172,20 & 227,18 & 2449,19 & 133,36 \\
\hline Mean & 4214,47 & 229,48 & 2026,55 & 110,35 \\
\hline Median & 4181,22 & 227,67 & 1970,16 & 107,28 \\
\hline Standard Deviation & 284,51 & 15,49 & 689,35 & 37,54 \\
\hline Coefficient of Variation & $6,75 \%$ & $6,75 \%$ & $34,02 \%$ & $34,02 \%$ \\
\hline
\end{tabular}

Table 2. Strength of joints made of natural ash wood and thermo-treated ash wood

This difference can be clearly seen in Figure 7. which shows curves of force-displacement diagrams of the tested specimens of tenon joint. The joints made of both type of materials had a wide defined elastic region. The values of displacements at ultimate applied load ranged from 4 to $8 \mathrm{~mm}$ for the natural ash wood joints and from 1 to $4 \mathrm{~mm}$ for the thermo-treated ash wood joints.

Values of ultimate bending moment of the joints $\left(M_{\max }\right)$, as a common joint strength indicator, were calculated using the expression which is given in the chapter on Experimental method. The support reactions were $F_{\mathrm{Amax}}=F_{\mathrm{Bmax}}=\mathrm{F}_{\max } / 2$ and moment arms, i.e. the distances from the support reactions to the force line, $a_{A}=a_{B}=102,53 \mathrm{~mm}$ for all tested joints, Fig. 2. and 4. The maximal bending moment of tenon joints made of thermo-treated ash wood was remarkably low and had about twice as lower value then the maximal bending moment of tenon joints made of natural ash wood. Certainly, the percentage of ratio of maximal moments of the joints made of thermo-treated ash wood and untreated ash wood had the same value as the percentage of ratio among the mean values of maximal forces of the joints constructed using those two ash woods. 


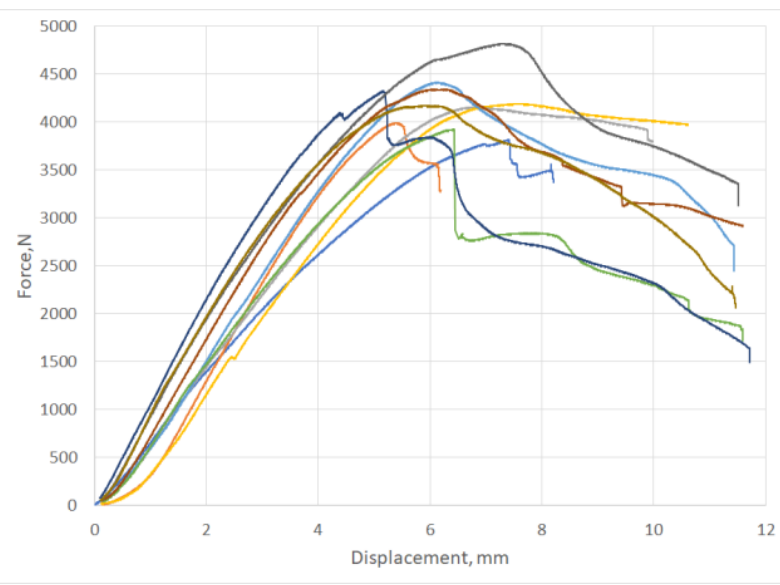

a)

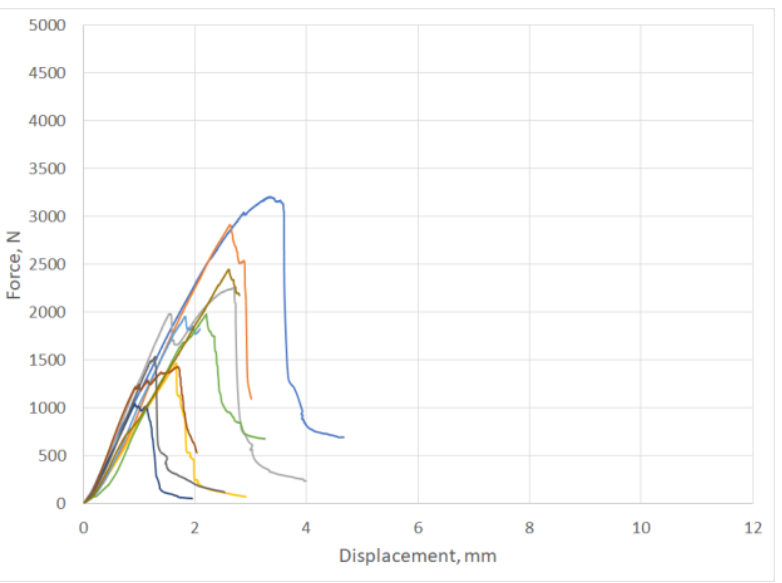

b)

Fig. 7. Working diagram of joint strength testing: a) ash wood, b) thermo-treated ash wood

The different pattern of ultimate fractures of joints made of untreated and treated ash wood was observed. A typical failure occurred at the untreated ash wood joints. The tenon started to take the load after the glue line failed and later it was partially pulled out from the mortise while a fracture of mortise wood occurred, as shown in Fig. 8a. In general, the failures of the thermo-treated wood joint samples were caused by a sudden fracture of tenon cross section and/or wood failures of mortise element in the form of wood fracture parallel and/or perpendicular to grain, Fig. 8b. Greater susceptibility to failures of the joint adhesive bond was not observed in thermo-treated wood joints compared to untreated wood joints.
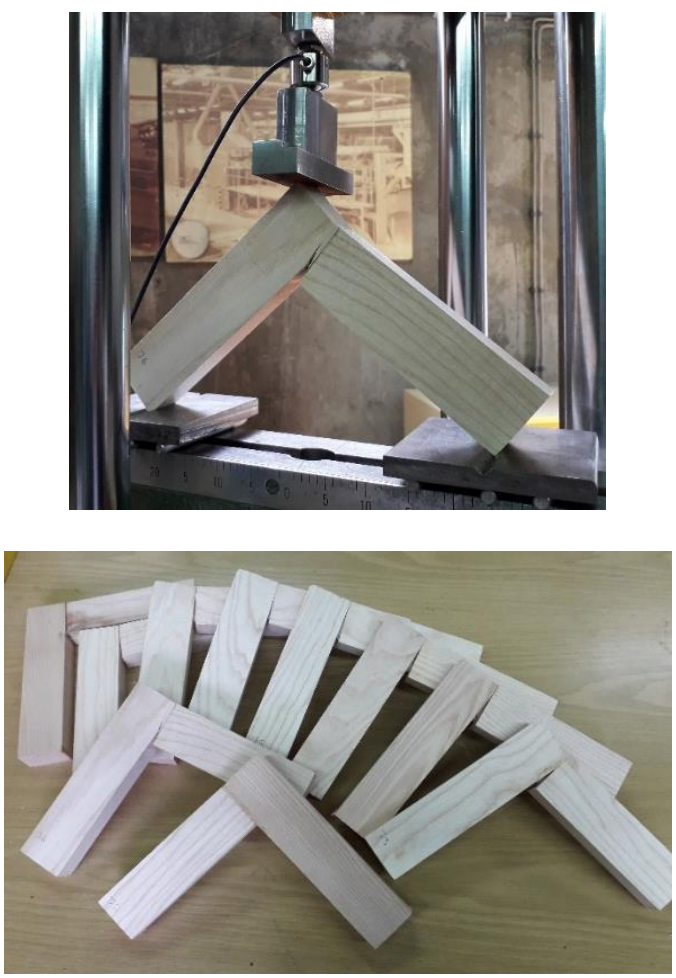

a)
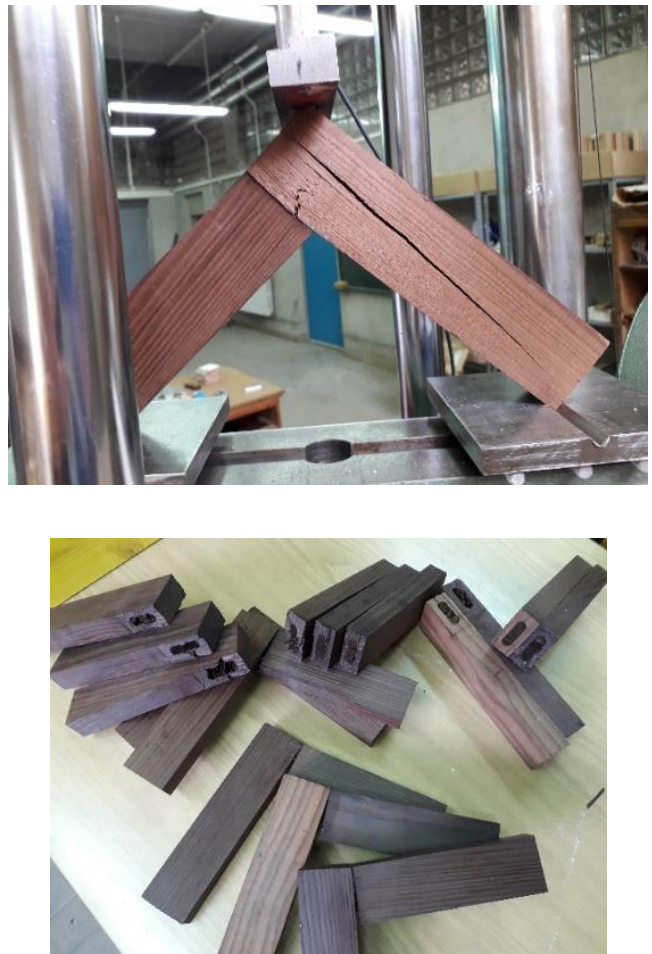

b)

Fig. 8. Cornet tenon joints failures: a) ash wood, b) thermo-treated ash wood

\section{Conclusion}

Maximal applied load and bending moment of untreated ash wood joints and thermo-treated ash wood joints were investigated. Also, selected physical and mechanical properties of natural and thermal-treated ash wood were determined. The test property results were consistent with data from literature and showed that technical properties of thermo-treated ash wood differed from natural ash wood. Equilibrium moisture content of thermo-treated ash wood was much lower compared with untreated ash wood. The compression strength parallel to grain values of thermo-treated ash wood was better than with untreated ash wood. Thermo-treated ash wood had lower bending strength compared to untreated ash 
wood and it was therefore more susceptible to failures in bending load. The corner tenon joint test results showed that the joints made of thermo-treated ash wood had much lower maximal force than those made of untreated ash wood. Identically, the result of calculations showed that the joints made of thermo-treated ash wood had a remarkably low and more than twice as low maximal bending moment of tenon joints made of untreated ash wood.

Thermal modification changed the technical properties of ash wood, reduced the construction potential of ash wood and, therefore, the joints of thermally modified ash wood have a remarkably reduced strength. Based on this, compared to natural ash wood, it has been shown that thermo-treated ash wood is less suitable for making common tenon joints and in use for load-bearing and heavily loaded joints and structures. Additional research needs to be done to determine the type, geometry and shape of tenon joint with minimal effect of thermo-treated wood and its bending strength.

\section{References}

[1] Hill, C. A. S. (2011). Wood modification: an update, BioResources 6(2), 918-919.

[2] Vukas, N.; Horman, I. \& Hajdarevic, S. (2010). Heat treated wood, Proceedings of 14th International Research/Expert Conference: "Trends in the Development of Machinery and Associated Technology" TMT 2010, 11-18 September 2010, Mediterranean Cruise, ISSN 1840-4944, Ekinovic, S. (Ed.), pp. 121-124.

[3] Esteves, B. M.; Domingos, I. J. \& Pereira, H. M. (2008). Pine wood modification by heat treatment in air, BioResources 3(1), 142-154.

[4] Fajdiga, G.; Zafošnik, B.; Gospodarič, B. \& Straže, A. (2016). Compression test of thermally-treated beech wood: eksperimental and numerical analysis, BioResources 11(1), 223-234, DOI:10.15376/biores.11.1.223-234

[5] Kasal, A.; Eckelman, C. A.; Haviarova, E.; Erdil, Y. Z. \& Yalcin I. (2015). Bending moment capacities of L-shaped mortise and tenon joints under compression and tension loadings, BioResources 10(4), 7009-7020, DOI: 10.15376/biores.10.4.7009-7020.

[6] Hajdarević, S. \& Martinović, S. (2014). Effect of tenon length on flexibility of mortise and tenon joint, Procedia Engineering 69, 678-685, DOI: 10.1016/j.proeng.2014.03.042.

[7] Hajdarević, S.; Obucina, M.; Mesic, E. \& Martinovic, S. (2020). Strength and stiffness analyses of standard and double mortise and tenon joints, BioResources 15(4), 8249-8267, DOI: 10.15376/biores.15.4.8249-8267.

[8] Martinovic, D.; Horman, I. \& Hajdarevic, S. (2008). Stress distribution in wood corner joints, Strojarstvo 50(4), 193-204, ISSN 0562-1887

[9] Hajdarevic, S.; Obucina, M.; Mesic, E. \& Martinovic, S. (2018). Stress and strain of the frontal parallel joints with 3D printed connectors, Proceedings of 29th DAAAM International Symposium on Intelligent Manufacturing and Automation, Zadar, pp. 0361-0368, B. Katalinic (Ed.), Published by DAAAM International, ISBN 978-3-90273420-4, ISSN 1726-9679, Vienna, Austria, DOI: 10.2507/29th.daaam.proceedings.052

[10] Likos, E.; Haviarova, E.; Eckelman, C. A.; Erdil, Y. Z. \& Ozcifci, A. (2012). Effect of tenon geometry, grain orientation, and shoulder on bending moment capacity and moment rotation characteristics of mortise and tenon joints, Wood and Fiber Science 44(4), 462-469.

[11] Derikvand, M.; Ebrahimi, G. \& Eckelman, C. A. (2014). Bending moment capacity of mortise and loose-tenon joints, Wood and Fiber Science 46(2), 1-8.

[12] Hrovatin, J.; Zupančič, A.; Šernek, M. \& Oblak, L. (2013). The fracture moment of corner joint bonded by different glues, Drvna Industrija 64 (4), 335-340, DOI: 10.5552/drind.2013.1248

[13] Kureli, I.; Altinok, M. \& Percin, O. (2013). Experimental investigation of some technological properties of thermo modified and impregnated wood samples, Wood Research, 58 (3):2013, 369-380.

[14] Barcík, Š.; Gašparík, M. \& Horejš, P. (2014). Influence of thermal modification on nail withdrawal strength of spruce wood, BioResources 9(4), 5963-5975.

[15] Georgescu, S. \& Bedelean, B. (2017). Effect of heat treatment on compressive and tensile strength of end to edge butt joint, Pro Ligno, Vol.13. No 4. pp.500-507, ISSN-L 1841-4737

[16] Kuzman, M. K.; Kutnar, A.; Ayrilmis, N. \& Kariz, M. (2015). Effect of heat treatment on mechanical properties of selected wood joints, Eur. J. Wood Prod, (2015) 73:689-691, DOI 10.1007/s00107-015-0931-z

[17] Tankut, N.; Tankut, A. N. \& Zor, M. (2014). Mechanical properties of heat-treated wooden material utilized in the construction of outdoor sitting furniture, Turk J Agric For, (2014) 38: 148-158, doi:10.3906/tar-1211-9

[18] Diler, H.; Acar, M.; Balikçi, E.; Demirci, S. \& Erdil, Y. Z. (2017). Withdrawal force capacity of T-type furniture joints constructed from various heat-treated wood species, BioResources 12(4) 7466-7478, DOI: 10.15376/biores.12.4.7466-7478.

[19] ISO 13061-17 (2017): Physical and mechanical properties of wood-Test methods for small clear wood specimensPart 17: Determination of ultimate stress in compression parallel to grain, International Organization for Standardization, Geneva, Switzerland

[20] ISO 13061-3 (2014): Physical and mechanical properties of wood-Test methods for small clear wood specimensPart 3: Determination of ultimate strength in static bending, International Organization for Standardization, Geneva, Switzerland

[21] ISO 13061-1 (2014): Physical and mechanical properties of wood-Test methods for small clear wood specimensPart 1: Determination of moisture content for physical and mechanical test, International Organization for Standardization, Geneva, Switzerland 